\title{
Physiological Analysis Reveals the Possible Resistance Mechanisms of Glycine max to Fusarium solani
}

\author{
George Bawa ${ }^{1,2}$, Lingyang Feng ${ }^{1}$, Yan $\mathrm{Li}^{1}$, Jing Shang ${ }^{1}$, Xiaoling Wu ${ }^{1}$, Xiaoli Chang ${ }^{1}$, Xin $\mathrm{Sun}^{1}$, Liang $\mathrm{Yu}^{1}$, \\ Chunyan Liu ${ }^{1}$, Junbo Du ${ }^{1} \&$ Wenyu Yang ${ }^{1}$ \\ ${ }^{1}$ College of Agronomy/Key Laboratory of Eco-physiology and Farming System in Southwest China (Ministry of \\ Agriculture), Sichuan Agriculture University, Chengdu, China \\ ${ }^{2}$ Ministry of Food and Agriculture/Ministry of Local Government and Rural Development, Ghana \\ Correspondence: Junbo Du, College of Agronomy/Key Laboratory of Eco-physiology and Farming System in \\ Southwest China (Ministry of Agriculture), Sichuan Agricultural University, Chengdu, China. E-mail: \\ junbodu@hotmail.com
}

Received: July 3, $2018 \quad$ Accepted: August 14, $2018 \quad$ Online Published: October 15, 2018

doi:10.5539/jas.v10n11p44 URL: https://doi.org/10.5539/jas.v10n11p44

This research is financed by the Science \& Technology Department of Sichuan Province (2018HH0108), National Natural Science Foundation of China (31671445, 31871552).

\begin{abstract}
Sudden death syndrome (SDS) of soybean is a complex root rot disease caused by the semi-biotrophic fungus Fusarium solani ( $F$. solani) and a leaf scorch disease; caused by toxins produced by pathogen in the roots. However, the mechanism of soybean resistant to $F$. solani is still poorly understood. Eighteen soybean cultivars were screened for SDS resistance, with one cultivar showing susceptibility and one cultivar showing resistance to F. solani infection. Histochemical analysis with diaminobenzidine (DAB) and Trypan blue staining indicated an accumulation of reactive oxygen species (ROS) and cell death in surrounding area of SDS which was higher in susceptible cultivar than in resistant cultivar. Furthermore, exogenous salicylic acid (SA) application also induced some level of resistance to $F$. solani by the susceptible cultivar. A biochemical study revealed that the activities of superoxide dismutase (SOD), peroxidase (POD), and enzymes involved in scavenging ROS, increased in susceptible cultivar after SDS infection. In addition, hydrogen peroxide $\left(\mathrm{H}_{2} \mathrm{O}_{2}\right)$ and malondialdehyde (MDA) content also increased in the susceptible cultivar than in resistant cultivar. High-performance liquid chromatography (HPLC) analysis indicated that free and total salicylic acid (SA) content increased in the susceptible cultivar than in resistant cultivar. In addition, a real-time quantitative PCR analysis showed an accumulation of pathogen related $(P R)$ genes in the resistant cultivar than in susceptible cultivar. Our results show that (i). F. solani infection can increase endogenous SA levels, antioxidase activities, ROS and cell death in susceptible soybean cultivar to induce resistance against Fusarium solani. (ii). F. solani infection induced the expression of SA marker genes in resistant soybean cultivar to enhance resistance.
\end{abstract}

Keywords: Fusarium solani, soybean, disease resistance, salicylic acid, antioxidants

\section{Introduction}

Soybean production is often affected by many diseases in major cropping areas (Wrather et al., 2010). Sudden death syndrome (SDS) caused by Fusaruim solani (F. solani) occurs frequently in the top eight soybean producing countries in the world (Wrather et al., 2010). SDS is associated with root rot, vascular discoloration of stems, root chlorosis and necrosis, defoliation and plant death (Roy et al., 1997). Mostly, SDS is more easily detected in soybean fields after flowering, when the leaves show interveinal choroids and necrosis. Meanwhile, SDS can be expressed in severe and mild forms. The occurrence and geographical distribution of pathogens causing the latter is unknown (Scandiani et al., 2011).

Exposure of plants to unfavorable conditions, makes them develop an integrated defense mechanism against fungal diseases which include chemical and physical barriers; and inducible defense (Dixon et al., 1994). So far as resistance responses other than susceptibility and immunity is concerned, the invasion of plant by fungal hyphae is likely to induce and sustain expression of some plant defense-related genes. Induced defenses attempts 
to prevent or reduce pathogen access by activating molecules that are antimicrobial, antioxidants, involved in the SA signaling pathways (Lamb \& Dixon, 1997). Phytohormones play important roles in regulating developmental process and signaling networks which are involved in plant response to a wide range of abiotic and biotic stresses (Robert-Seilaniantz et al., 2007; Bari \& Jones, 2009). Three major signaling molecules, Salicylic acid (SA), Jasmonic acid (JA) and Ethylene (ET) are recognized as major defense hormones against various pathogens (Glazebrook et al., 2003; De et al., 2005; Koornneef \& Pieterse, 2008). SA is associated with resistance against biotrophic and hemibiotrophic pathogens, and with triggering systematic acquired resistance (SAR) in many species including Arabidopsis thaliana and wheat (Triticum aestivum) (Görlach et al. 1996). Induction of SAR is accompanied by accumulation of SA and up-regulation of a set of genes encoding pathogenesis-related $(P R)$ proteins in dicot plants such as tobacco (Nicotiana tabacum) and Arabidopsis thaliana providing a wide range of protection against pathogens (Ward et al., 1991; Uknes et al., 1992). The elevated expression of defense genes have been assumed as a molecular evidence of induced resistance (Sumayo et al., 2014). Natriuretic Peptide Receptor 1 (NPRl) gene is a key regulator of the SA signaling pathways (Yan \& Dong, 2014). Enhanced Disease Susceptibility 1 (EDS1) gene was important for mediating resistance to a broad range of pathogens (viral, bacterial and fungal pathogens) yet showed specificity to the class of resistant $R$ genes that it affected (Hu et al., 2005). The EDS1 protein has been found to be complex with both the pathogen effectors and their cognate proteins and partitioning of the EDS1 complex in the cytoplasm nucleus is required for full activation of local resistance (Zheng \& Dong, 2013). EDS1 is required to induce SA biosynthesis (Zheng \& Dong, 2013).

Also, Chitosan which is used in agriculture in seed treatment and biopesticide helping plants to fight off against fungal infections, induced a significant increase in the activities of polyphenoloxidase, peroxidase, and enhanced the content of phenolic compounds in tomato fruits, thus providing protection against gray mould and blue mould diseases (Liu et al., 2007). Plants resistance can be induced by application of synthetic compounds such as functional analogs of SA, for example benzothiadiazole-7-carbothioic acid (acibenzolar-S-methyl) or benzothiadiazole (BTH). It has been shown that BTH which is a nontoxic compound, induced systematic resistance by exogenous root-treatment in tomato and controlled crown and root rot caused by F.oxysporum radices-lycopersici (Benhamou \& Bélanger, 1998). Fusarium wilt of tomato was effectively controlled by foliar spray of validamycin A or validoxylamine A, which induced SA accumulation and development of systematic resistance (Ishikawa et al., 2005). Exogenous application of SA induces plant resistance to different kinds of pathogens that are associated with oxidative burst, cell wall enforcement and up-or down-regulation of gene expression (Oostendorp et al., 2001).

Production of ROS such as the superoxide anion $\left(\mathrm{O}_{2}{ }^{-}\right)$and hydrogen peroxide $\left(\mathrm{H}_{2} \mathrm{O}_{2}\right)$, as one of the earliest response to pathogen attack, can trigger hypersensitive cell death. Abnormally high production of ROS causes damage to biomolecules, whereas ROS at moderate concentrations act as a second messenger in signal cascades that mediate several responses in plant cells including program cell death (Sharma et al., 2012). The hypersensitive response (HR), as an early defense response, restricts pathogen infection to the site of attempted ingress by necrosis and cell death. Plants have an efficient antioxidative, enzymatic and non-enzymatic protective mechanisms to scavenge excess ROS. Several antioxidative enzymes including superoxide dismutase (SOD), catalase (CAT), and peroxidase (POX) are involved in detoxification of ROS (Zhang et al., 1995; D. H. Lee \& C. B. Lee, 2000).

Although much efforts have been made to identify mechanisms of resistance against SDS, much remains to be elucidated about the physiological and molecular capabilities of the soybean plant against $F$. solani infection. Here we performed a comparative study between resistant and susceptible soybean cultivars to distinguish the effects of some antioxidant and biosynthetic enzymes in response to $F$. solani infection. We also investigated the effect of exogenous application of SA, as a key factor in SAR, on soybean resistance to $F$. solani infection. Finally, to identify possible $P R$ genes involved in the resistance process between the resistant and susceptible cultivar, RT-qPCR analysis was performed.

\section{Materials and Methods}

\subsection{Plant Materials and Chemicals}

Eighteen soybean cultivars used in the study were provided by Key Laboratory for Crop Genetics and Breeding of Sichuan Agricultural University, China. Seeds were surface-sterilized for $20 \mathrm{~min}$ in a $20 \%$ solution of sodium hypochlorite and then rinsed three times with sterilized water. Seeds were grown in an $11.5 \mathrm{~cm}$ diameter paper cups filled with perlite and placed in a climatically grown chamber. Conditions in the growth chamber included day/night at a regulated temperature of $25^{\circ} \mathrm{C}$. Watering was done as required to promote seed germination. 


\subsection{Fungal Growth and Inoculation}

The fungi Fusarium solani isolate 2 hao3 was provided by the Key Laboratory for Major Crop Diseases of Sichuan Agricultural University, China. Isolate was obtained from soybean roots and preserved on potato dextrose agar (PDA) prior to sub cultures. $2 \mathrm{~mm}$ plug from the stock culture was used for sub cultures for inoculation by placing fungal isolate on PDA medium in petri dishes. The fungus was incubated at a temperature of $28{ }^{\circ} \mathrm{C}$ for 7 days in the dark in a growth chamber. The seedlings were removed from the perlite after 3-day growth period and washed with distilled water prior to inoculation. Inoculation was performed by using the hypocotyl inoculation method described previously by (Haas \& Buzzell, 1976). Disease development was observed for 2 days. Control plants were inoculated with 7 days grown PDA on a petri dish without fungus. Fungal inoculated and non-fungal inoculated seedlings were placed in a growth chamber at a temperature range of about $25^{\circ} \mathrm{C}$ without light condition.

\subsection{Screening and Disease Assessment}

Assessment of disease severity on all the 18 soybean cultivars was done according to (Ishikawa et al., 2005) with some modifications. At 2 days post inoculation (dpi) by F. solani the disease index (on 1-5 scale) on each plant was recorded according to vascular browning and the mean value of 10 plants from each cultivar calculated for disease severity. For evaluation of vascular browning, the basal stems were cut and vascular browning was rated on a scale of $1-5$; where $1=$ no symptoms or vascular browning; $2=1-25 \%$ vascular; $3=6-50 \%$ vascular browning; $4=51-75 \%$ vascular browning; $5=$ more than $75 \%$ vascular browning. The mean value recorded for Nandou12 was $1=$ no symptoms and Juiyuehuang recorded $5=$ more than $75 \%$ vascular browning (Figure 1). These formed our basis for selecting Nandou12 as resistant and Juiyuehuang as susceptible cultivars.

\subsection{Histo-chemical Stainings}

Tissue staining with Trypan blue $(1.25 \mathrm{mg} / \mathrm{ml}$, sigma $)$ and DAB $(1 \mathrm{mg} / \mathrm{ml}$, sigma) was performed as previously described (Thordal-Christensen et al., 1997; Shirasu et al., 1999; Lam, 2004) with suitable modifications. Samples were stained at 48 hours post inoculation (hpi).

\subsubsection{Exogenous SA Application}

To determine whether exogenous SA application can induce systematic acquired resistance in soybean, we first sprayed (For $48 \mathrm{~h}$ : at every $6 \mathrm{~h}$ intervals) the seedlings with SA which was dissolved in deionized water at a concentration of $100 \mu \mathrm{M}$ and $200 \mu \mathrm{M}$ in order to compare the disease development to seedlings inoculated with fungus without exogenous SA application. This assay was conducted as previously described (Spletzer \& Enyedi, 1999).

\subsubsection{Reverse Transcription and Quantitative PCR (RT-qPCR) Analysis}

Total RNA was extracted using a plant total RNA Miniprep purification Kit (Tiangen, http://www.tiangen.com/) cDNA was reversely transcribed from $2 \mu \mathrm{g}$ of total RNA using an oligo $\mathrm{dT}_{20}$ primer and MLV reverse transcriptase (http://www.invitrogen.com). First strand cDNAs of reversely transcribed 50ng of RNA was used for semi-quatitative RT-PCR analysis Extaq DNA polymerase (TaKaRa) and qPCR with Universal SYBR ${ }^{\circledR}$ GREEN qPCR Master Mix (2×) (Gangchi Bio). The parameters of the semi-quantitative PCR were as follows: $95^{\circ} \mathrm{C}$ for 5 min, $95{ }^{\circ} \mathrm{C}$ for $15 \mathrm{~s}, 50{ }^{\circ} \mathrm{C}$ for $30 \mathrm{~s}, 72{ }^{\circ} \mathrm{C}$ for $1 \mathrm{~kb} \mathrm{~min}^{-1}$, and another cycle (step 2) was repeated according to the gene expression level of the specific genes. Parameters of the qPCR were as follows $95^{\circ} \mathrm{C}$ for $3 \mathrm{~min}, 95^{\circ} \mathrm{C}$ for $15 \mathrm{~s}$ and $55^{\circ} \mathrm{C}$ for $15 \mathrm{~s}$, and $72{ }^{\circ} \mathrm{C}$ for $20 \mathrm{~s}$, go to step 2 for 39 more cycles. Then increment of $0.5^{\circ} \mathrm{C}$ from $65^{\circ} \mathrm{C}$ to $95{ }^{\circ} \mathrm{C}$ for 5 seconds was used for melt curve analysis. $\Delta \Delta \mathrm{Cq}$ method was used to normalize the qPCR data according to (Du et al., 2016). GmACT3 (Glyma09g17040) was amplified as an internal control. Gene-specific primer pairs were designed using Primer 5.0 (Table 1).

\subsubsection{Endogenous SA Measurement}

SA was extracted and measured according to modification from previous studies (Wang et al., 2011). $200 \mathrm{mg}$ of soybean tissue was ground to fine powder with $\mathrm{N}_{2}$ and extracted once with $1.5 \mathrm{ml}$ of $90 \%$ methanol followed by one extraction with $1.5 \mathrm{ml}$ of $100 \%$ methanol. The methanol fraction was equally split into two micro centrifuge tubes (for total and free SA analyses, respectively) and dried in the fume hood overnight. The pellet was dissolved by adding $500 \mu \mathrm{l}$ of $100 \mathrm{mM}$ sodium acetate (pH 5.5). To half of the duplicated samples, $40 \mu \mathrm{l}$ of $\beta$-glucosidase (Sangon, A662003-0010) were added to digest glucosyl-conjugated SA (total SA) for $1.5 \mathrm{~h}$ at $37^{\circ} \mathrm{C}$. (About 80 units/g fresh weight). All the samples were treated with an equal volume of $10 \%$ trichloroacetic acid (TCA) and centrifuged at 10,000g for $10 \mathrm{~min}$. The supernatant was extracted twice with $1 \mathrm{ml}$ of extraction solvent (ethylacetate: cyclopentane: 2-propanol 100:99:1, v/v). The top (organic) phase was collected in a micro centrifuge tube and dried in a fume hood overnight. The residual fraction was re-suspended in $0.5 \mathrm{ml}$ of $55 \%$ 
methanol by vortex and was passed through a 0.2-um nylon spin-prep membrane (Fisher 07-200-389) via centrifugation for $2 \min (14,000 \mathrm{~g})$ before being subjected to HPLC analysis. A Dionex AS50 HPLC instrument with an Acclaim 120C18 reverse column $(4.6 \times 250 \mathrm{~mm})$ and an RF2000 fluorescence detector was used to separate and detect SA. The mobile phase included a gradient of methanol and $0.5 \%$ acetic acid. SA was detected at $6.5 \mathrm{~min}$ with $301-\mathrm{nm}$ excitation/412-nm emission. The standard curve was made from quantification of SA at concentration of $10,8,6,2$, and $1 \mathrm{mg} \mathrm{mL}^{-1}$ and used to calculate the final concentration in each sample using Microsoft Excel software.

\subsubsection{Determination of Antioxidant Enzymatic Activity}

The enzymes activity was carried out by grinding $0.5 \mathrm{~g}$ of 2 days infected soybean tissues with $2 \mathrm{~mL}$ ice-cold 25 $\mathrm{mM}$ HEPES buffer (pH 7.8) containing 0.2 mM, EDTA, $2 \mathrm{mM}$ ascorbate and $2 \%$ PVP. Further, the homogenates were centrifuged at $4{ }^{\circ} \mathrm{C}$ for 15 minutes at $13,000 \mathrm{~g}$ and the supernatant was used for enzyme activities analysis. All the various steps in the preparation of the enzyme extract were carried out at $4{ }^{\circ} \mathrm{C}$. Peroxidase (POD) activity was measured according (Egley et al., 1983), the total volume of $2 \mathrm{~mL}$ mixture contained $25 \mathrm{mM}(\mathrm{Ph} 7.0)$ sodium phosphate buffer, $0.1 \mathrm{mM}$ EDTA, $5 \%$ guaiacol (2-ethoxyphenol), $1.0 \mathrm{mM} \mathrm{H} \mathrm{H}_{2}$ and $100 \mu \mathrm{l}$ enzyme extract. Superoxide dismutase (SOD) activity was also measured as previously described (Giannopolitis and Ries 2010).

\subsection{5 $\mathrm{H}_{2} \mathrm{O}_{2}$ Measurement}

Hydrogen peroxide $\mathrm{H}_{2} \mathrm{O}_{2}$ content from the 2days infected soybean tissues was measured according to (Du et al., 2011). About $1 \mathrm{~g}$ of soybean hypocotyl was homogenized in an ice bath with $5 \mathrm{ml} 0.1 \%(\mathrm{w} / \mathrm{v}) \mathrm{TCA}$. The homogenate was transferred into a tube and centrifuged at $12,000 \mathrm{~g}$ for $20 \mathrm{~min}$ at $4{ }^{\circ} \mathrm{C} .0 .5 \mathrm{ml}$ of the supernatant was added to $0.5 \mathrm{ml} 10 \mathrm{~mm}$ potassium phosphate buffer (Ph.7.0) and $1 \mathrm{ml}$ potassium iodide (KI). The absorbance of supernatant was read at $390 \mathrm{~nm} . \mathrm{H}_{2} \mathrm{O}_{2}$ content was determined by a standard curve.

\subsubsection{Malondialdehyde (MDA) Content Measurement}

MDA content of the 2days infected soybean tissues was quantified according to (Sun et al., 2006; Qian et al., 2007). About $1 \mathrm{~g}$ of soybean tissues (hypocotyl) was homogenized with $5 \%$ trichloroacetic acid (TCA) on ice and centrifuged at $3,000 \mathrm{~g}$ for $10 \mathrm{~min}$ at $4{ }^{\circ} \mathrm{C} .2 \mathrm{~mL}$ of the supernatants was transferred into another tube added with $2 \mathrm{ml} 0.67 \%$ thiobarbituric and incubated at $100^{\circ} \mathrm{C}$ for $15 \mathrm{~min}$. The cooled mixture was centrifuged at 4,000 $\mathrm{g}$ for $10 \mathrm{~min}$. The supernatants were subjected to analysis at $450 \mathrm{~nm}\left(\mathrm{~A}_{450}\right) 532 \mathrm{~nm} 600 \mathrm{~nm}\left(\mathrm{~A}_{600}\right)$ in spectrometer The amount of MDA was calculated using an extinction coefficient of $155 \mathrm{Nm}^{-1} \mathrm{~cm}^{-1}$ and according to the formula: $\operatorname{MDA}\left(\mu \mathrm{mol} \mathrm{L}^{-1}\right)=6.45 \times\left(\mathrm{A}_{532} \mathrm{~A}_{600}\right)-0.56 \times \mathrm{A}_{450}$.

\subsection{Statistical Analysis}

All experiments were repeated three times, with three replication each. Statistical calculations were performed using SPSS-20 (SPSS, Chicago, IL, USA). For disease severity assessment, a minimum of ten plants were evaluated for each replicate. Tests for significant difference among physiological parameters under different treatment were conducted using analysis of variance (ANOVA) with mean separation using Duncan's multiple range tests (DMRT) at the 0.05 level of confidence.

\section{Results}

\subsection{Phenotypic Expression of Soybean Seedlings to F. solani Infection}

In the current study, 18 soybean cultivars were evaluated for SDS resistance to $F$. solani infection. Inoculated seedlings were monitored and disease symptoms were recorded at 2 dpi. Jiuyuehuang showed severe disease symptoms under $F$. solani infection whiles Nandou12 showed no disease symptoms (Figure 1; Figure 2: JT and NT). Once the symptoms of the disease appeared, fungal inoculated and non-fungal inoculated plants were collected at $2 \mathrm{dpi}$. The appearance of the symptoms provided a confirmation that the pathogen had penetrated the host tissues and infection was successful. Visual disease assessment (VDS) was used to evaluate the resistance level between the two soybean cultivars. See Materials and Methods section for details. 


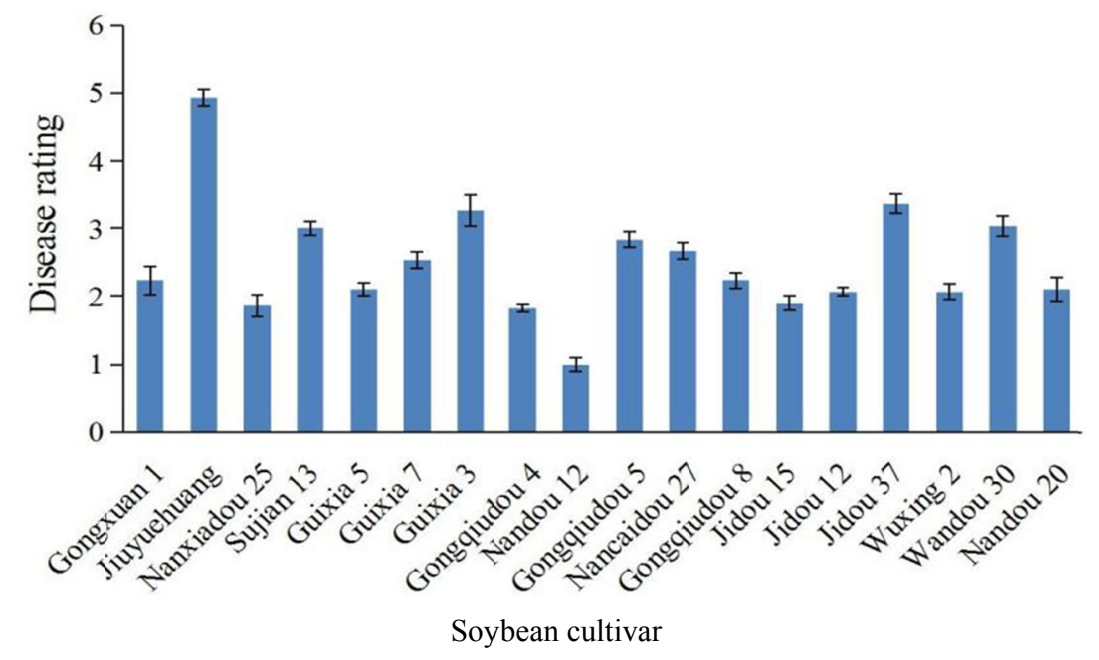

Figure 1. Response of 18 soybean cultivars to sudden death syndrome (SDS). Data on vascular browning of the stems were recorded at 2 dpi of soybean plants by Fuasrium solani. Columns represent the mean disease ratings on 1-5 scale as described in Materials and methods section. Data bars are the means $\pm \mathrm{SD}$ of three replicates. The experiments were repeated three times with three replicates

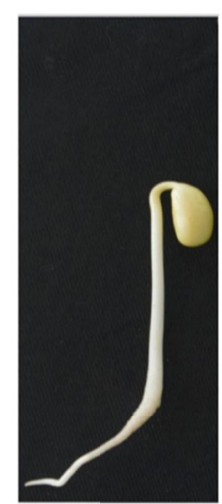

NC
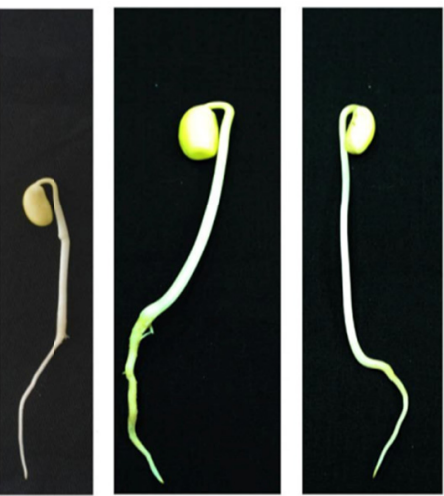

NT $100 \mu \mathrm{M}$ SA $200 \mu \mathrm{M}$ SA

Nandou-12
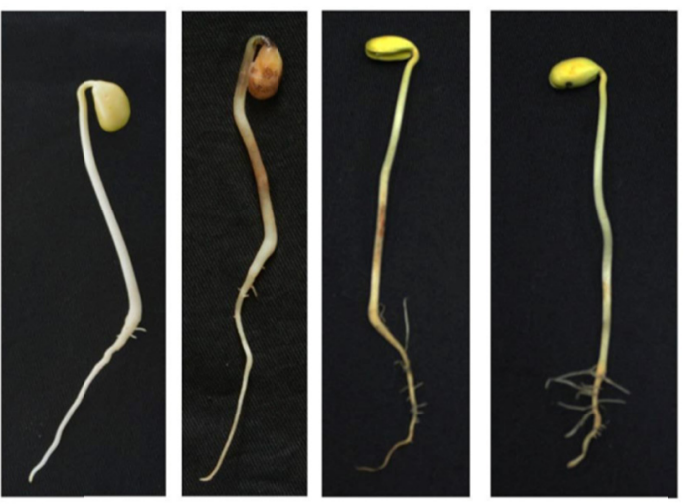

JT $100 \mu \mathrm{M}$ SA $200 \mu \mathrm{M} \mathrm{SA}$

\section{Jiuyuehuang}

Figure 2. Early symptoms of Soybean sudden death syndrome (SDS) induced artificially by inoculating with

Fusarium solani at 2 dpi. NC: Nadou12 control; NT: Nadou12 treatment; JC: Jiuyuehuang control; JT: Jiuyuehuang treatment. And in order to observe the effect of exogenous SA application on inducement of disease resistance, different SA concentrations $(100-200 \mu \mathrm{M})$ were sprayed (For $48 \mathrm{~h}$ : for every $6 \mathrm{~h}$ intervals) on different soybean seedlings of the same cultivars prior to fungal inoculation 


\subsection{Histo-chemical Stainings}

Results from the histo-chemical staining showed a higher intensity of diaminobenzidine (DAB) and programmed cell death (PCD) in Jiuyuehuang than in Nadou12 (Figures $3 \mathrm{~b}$ and 3d) and (Figures $4 \mathrm{~b}$ and $4 \mathrm{~d}$ ) respectively. Through staining, it was observed that the tissue with DAB stained brownish at the infected or penetrated site. Likewise cells with PCD stained deep blue at the infected site as a result of fungal infection.
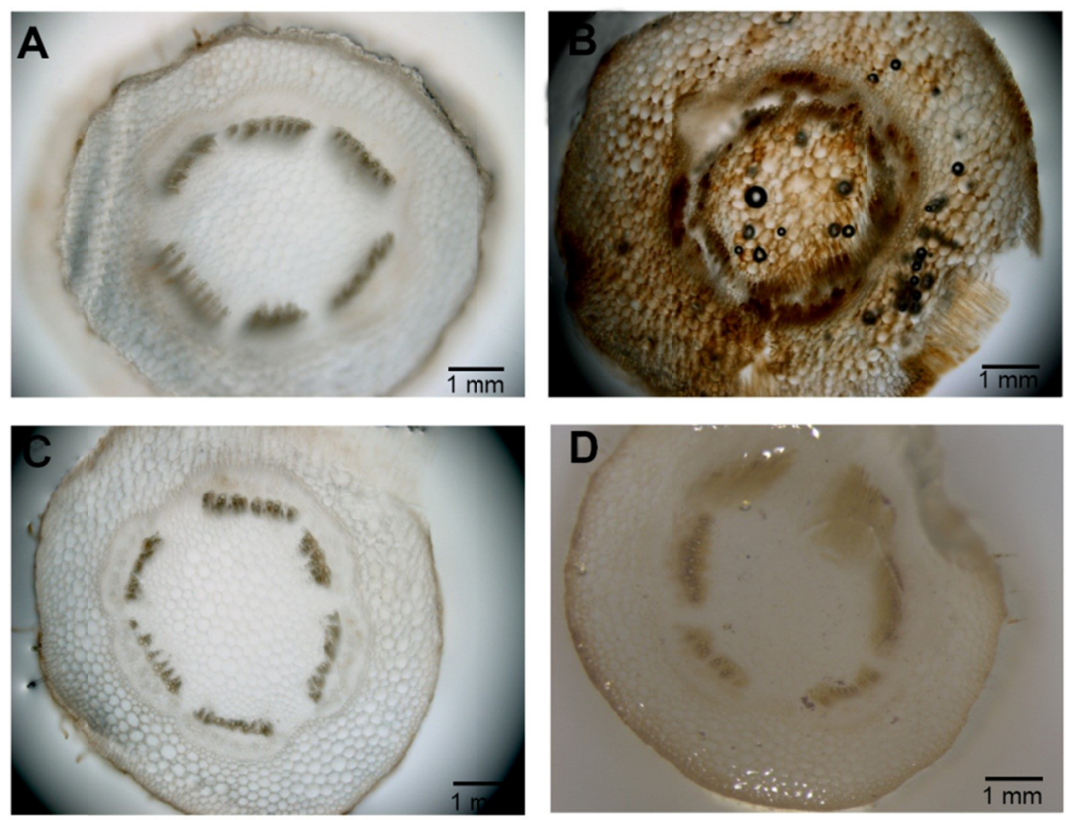

Figure 3. Cross sectional hypocotyl levels of ROS was visualized by DAB-staining at $48 \mathrm{hpi}$ with $F$. solani. (A): Jiuyuehuang control; (B): Jiuyuehuang treatment; (C): Nadou12 control; (D): Nadou12 treatment. Scale bars represents $1 \mathrm{~mm}$
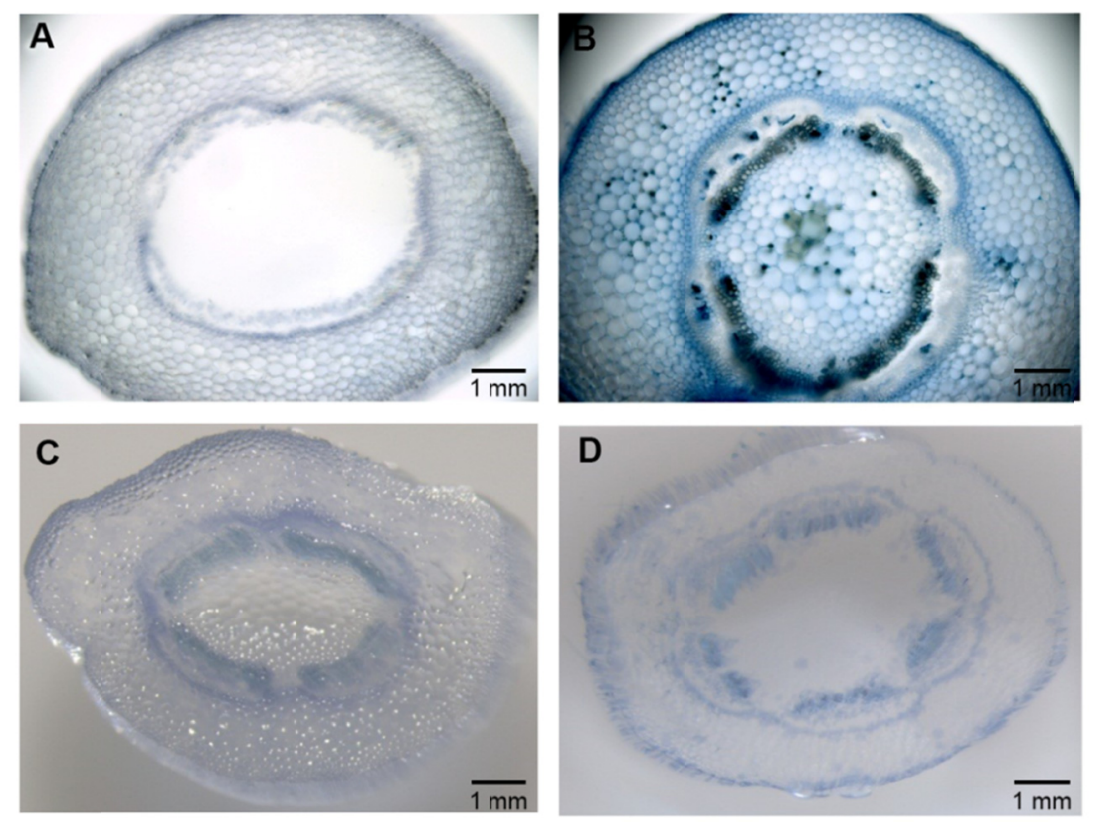

Figure 4. Cross sectional hypocotyl levels of plant cell death was visualized by Trypan blue staining at 48hpi with F. solani. (A): Jiuyuehuang control; (B): Jiuyuehuang treatment; (C): Nadou12 control; (D): Nadou12 treatment. Scale bars represents $1 \mathrm{~mm}$ 


\subsection{Exogenous SA Treatment of Soybean Seedlings Induced Resistance Against F. solani}

Exogenous SA application results indicated that, exogenous SA application induces systematic acquired resistance in soybean. Vascular brown level in Jiuyuehuang (Figure 2: JT) reduced significantly after exogenous SA feeding of $200 \mu \mathrm{M}$ prior to inoculation. No difference was observed in Nadou12 after the exogenous SA application.

\subsection{Detection of SA From Soybean Seedlings}

The effect of SA on plants response to pathogenes in susceptible and resistant cultivars under $F$. solani infection was investigated. Results from the study suggest that endogenous SA content in soybean can be increased under F. solani infection. F. solani infection induced Free/Conjugated SA content in Jiuyuehuang than in Nadou12 (Figure 5).
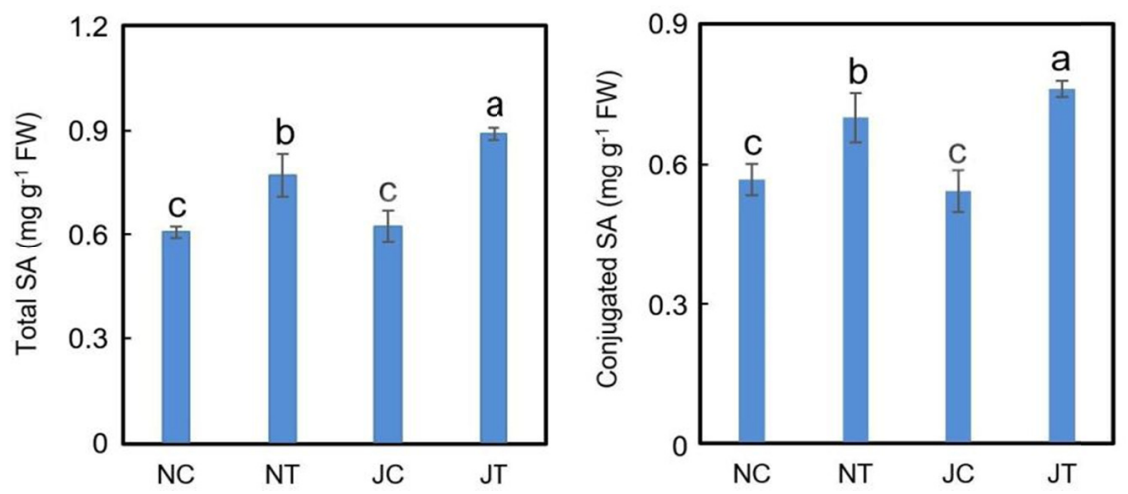

Figure 5. Accumulation of salicylic acid (Total and Conjugated SA) in soybean tissue at 48 hpi with F. solani. (NC) Nadou12 control; (NT)-Nadou12 treatment; (JC)-Jiuyuehuang control, (JT) Jiuyuehuang treatment. Data bars are the means $\pm \mathrm{SD}$ of three replicates. Letters indicate significant differences $(\mathrm{P}<0.05)$ according to

Duncan's multiple range tests

\subsection{Temporal Expression of Defense-Related Genes}

We monitored the differential expression of genes related to biotic- stress responses. From all the treatments there was some advancement in the expression of SA and PR- related genes. Most of the genes were unregulated in the resistant cultivar than in the susceptible cultivar. At 24 hpi the relative expression of NPR1, PR1, PAD4, $E D S 1, E D S 5$ and SID2 was higher in the resistant cultivar (Nandou12) than in the susceptible cultivar (Jiuyuehuang) (Figure 6). This result indicates that $F$. solani inoculation induced higher $P R$ genes at $24 \mathrm{hpi}$ in Nadou12 than in Jiuyuehuang. Similarly, at 48 hpi there was a higher expression of PR1 and SID2 in the susceptible cultivar than in resistant cultivar. PAD4 and EDS5 also expressed a little higher in the resistant cultivar than in susceptible at 24 hpi. In contrast, EDS1 expression level in Jiuyuehuang than in Nadou12. 

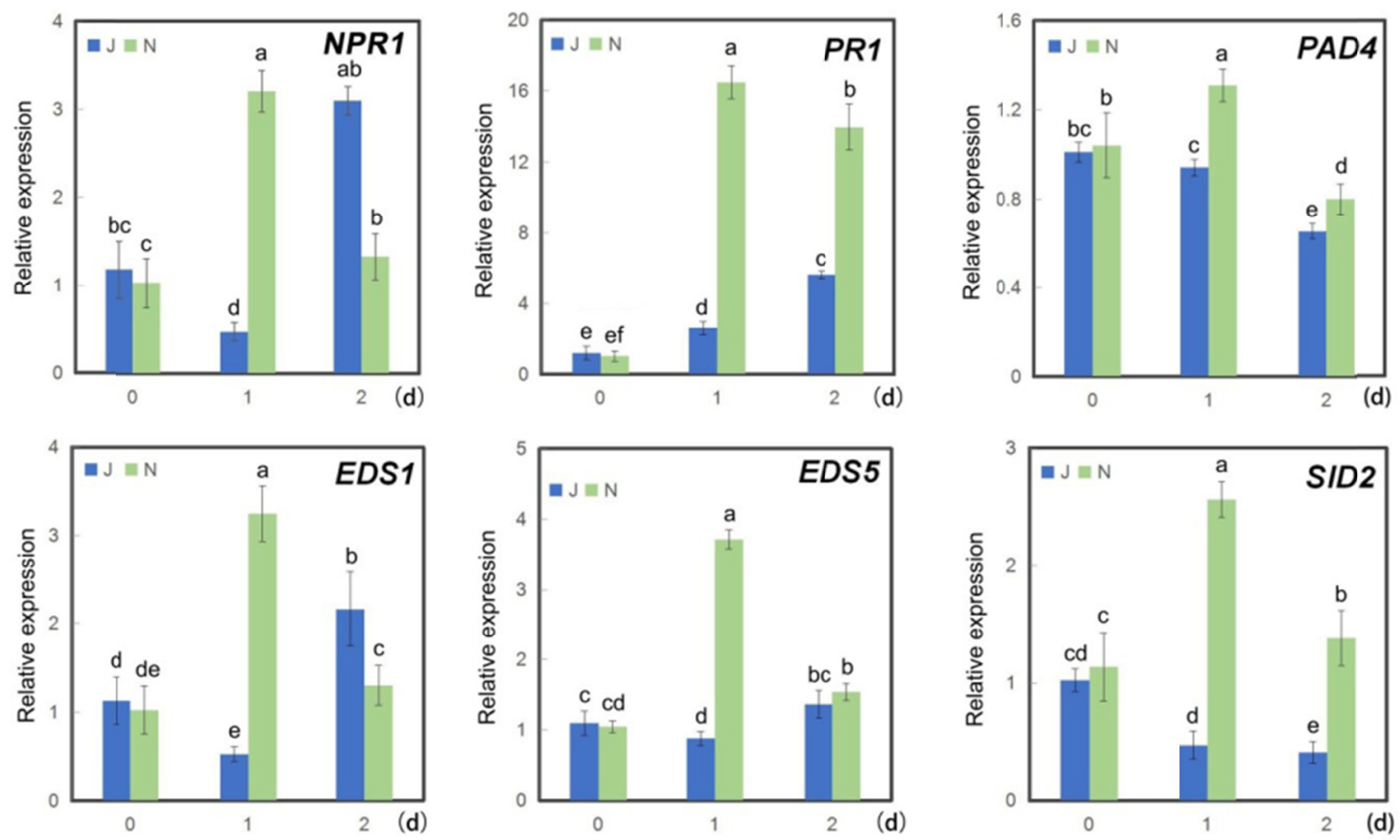

Figure 6. Relative expression of GmNPR, GmPR1, GmPAD4, GmEDS1, GmEDS5, GmSID2 in two varieties of soybean (Glycine max L.), Jiuyuehuang $(\mathrm{J})$ and $\operatorname{Nandou} 12(\mathrm{~N})$, at $0,1,2$ days (d) as determined by fluorescent quantitation PCR analysis. Error bars indicate $\mathrm{SD}(\mathrm{N}=3)$. Lowercase letters significant difference from Jiuyuehuang at 0 day (Student's $t$ test, $\mathrm{p}<0.01$ )

Table 1. Primer sequences used in RT-qPCR analysis

\begin{tabular}{|c|c|c|c|}
\hline GENE ID & GENE NAME & & qPCR PRIMER( $\left(5^{\prime}\right.$ to $\left.3^{\prime}\right)$ \\
\hline \multirow[t]{2}{*}{ Glyma15g06790 } & GmPRI & Forward & CGCTGCTTTTGCACAGAACTA \\
\hline & & Reverse & CTCCCCGTATTTTCCATCAC \\
\hline \multirow[t]{2}{*}{ Glyma09g02430 } & GmNPRI-1 & Forward & CTCTGGGTTCTCTGGCATCA \\
\hline & & Reverse & ACACAGCCACCCCAGAAAAC \\
\hline \multirow[t]{2}{*}{ Glyma $04 \mathrm{~g} 34800$} & GMEDSI & Forward & CACTCCTCTGGTGCTGCAAT \\
\hline & & Reverse & TGGCGTGGGTTTTTGGAT \\
\hline \multirow[t]{2}{*}{ Glyma01g25690 } & GmSID $2 / G m I C S 1$ & Forward & GTCAGCATTGGTGGAAAAGG \\
\hline & & Reverse & TCATCCCACTCCAGGTAAGG \\
\hline \multirow[t]{2}{*}{ Glyma11g11970 } & GmEDS5 & Forward & ATATCGAGGCAGGGTGAGAA \\
\hline & & Reverse & AGTTGCTGGTCCTGTGAACA \\
\hline \multirow[t]{2}{*}{ Glyma08g00420 } & $G M P A D 4$ & Forward & AAGAGAGCCAAGTGGGTGAA \\
\hline & & Reverse & ATGCATCCССТTCCCATAAT \\
\hline
\end{tabular}

\subsection{Activities of Antioxidant Enzymes}

As indicators of antioxidants response in plants, the current study observed an increase in peroxidase (POD) and superoxide dismutase (SOD) activities in Jiuyuehuang than in Nadou12 (Figures $7 \mathrm{a}$ and $7 \mathrm{~b}$ ). Increased and decrease in antioxidants activity in plants have frequently been correlated with disease resistance and susceptibility. As indicators of oxidative stress, malondialdehyde (MDA) and hydrogen peroxide $\mathrm{H}_{2} \mathrm{O}_{2}$ content was determined for both cultivars. From the current study, the content of MDA and $\mathrm{H}_{2} \mathrm{O}_{2}$ was higher in Jiuyuehuang than in Nadou12 (Figures 7c and 7d). 

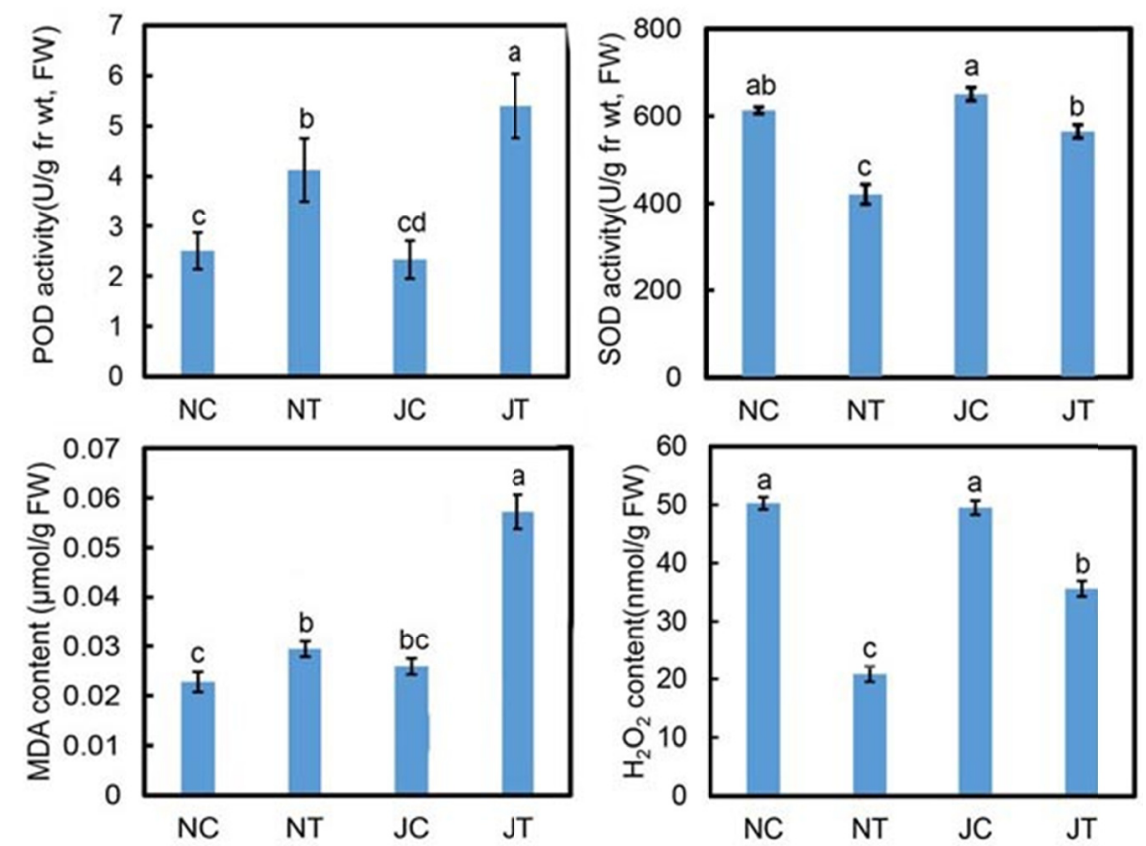

Figure 7. Antioxidants activity on two soybean cultivars at $48 \mathrm{hpi}$ after with $F$. solani. (a) Peroxidase (POD) content; (b) Superoxide dismutase (SOD) content; (c) Malondialdehyde (MDA) content; (d) Hydrogen peroxide $\left(\mathrm{H}_{2} \mathrm{O}_{2}\right.$ ) content; (NC)-Nadou 12 control; (NT)-Nadou12 treatment; (JC)-Jiuyuehuang control, (JT)-Jiuyuehuang treatment. Letters indicate significant differences $(\mathrm{P}<0.05)$ according to Duncan's multiple range tests. Data bars are the means $\pm \mathrm{SD}$ of three replicates

\section{Discussion}

The current study investigated a temporal resistance response between two soybean cultivars (Nadou12 and Jiuyuehuang) to $F$. solani infection. Our results provide a novel insight into the $F$. solani soybean interaction by analyzing plant pathogen defense response assays. Our assessment was based on physiological and molecular assays. SA is well known for its endogenous signal molecule playing an important role in development of systematic acquired resistance in plants (Dempsey et al., 1997). SA application induces accumulation of PR proteins (Loake \& Grant, 2007). Many of the PR proteins have antimicrobial activity in vitro and they serve as molecular markers for the onset of disease responses (Durrant \& Dong, 2004). Application of Exogenous SA and its functional analog potentiated plant tissue to respond rapidly and effectively to a variety of defense mechanisms after pathogen challenge (Katz et al., 1998). Our exogenous SA application showed a decrease in disease levels in Jiuyuehuang which suggested that exogenous SA application induced the endogenous SA level leading to the disease resistance. This observation has some similarities to a recent report that exogenous application of $200 \mu \mathrm{M} \mathrm{SA}$ to tomato plants prior to inoculation provided increased $F$. oxysporum resistance as evidenced by reduced foliar necrosis and plant cell death in Arabidopsis (Edgar et al., 2006). Similar response was also observed in tobacco plants treated with $100 \mu \mathrm{M} \mathrm{SA}$ (Oostendorp et al., 2001). All these suggest that, exogenous SA application plays a significant role in inducing SAR.

In the present study, a significant increase of ROS was observed in Jiuyuehuang than in Nadou12 through DAB staining (Figures $3 \mathrm{~b}$ and $3 \mathrm{~d}$ ). Accumulation was stronger and more intense in Jiuyuehuang. These results suggest that the induction of ROS in Jiuyuehuang maybe a defense responses against the invading pathogen. In a similar study, the inoculation of Botritis cinera induced an oxidative burst in Arabidopsis thaliana, and the aggressiveness of this pathogen was directly dependent on the level of ROS accumulation (Levine, 2000). The same was also reported by (Singh \& Upadhyay, 2014) where Ferric acid - treated tomato leaves exhibited visible necrotic lesions as a result of cell death which was evident by Evans blue staining, due to enhanced ROS levels and DNA damage. In the current study, increased accumulation of cell death was also observed in Jiuyuehuang at the site of infection than in Nadou12 which indicates a defense response against the attacking pathogen.

Plants infected by different pathogens induce different hormonal signaling pathways (Wege \& Siegmund, 2007). Salicylic acid (SA) and jasmonic acid (JA) signaling pathways are two most important pathways for plant 
response to fungal infection (Luo et al., 2011). SA pathways is often induced by pathogen infection and is effective in mediating resistance against biotrophic pathogens (Thaler et al., 2012). SA signaling was shown to be important in defense against $F$. graminaruim infection in $A$. thaliana and in wheat (Makandar et al., 2006; Makandar et al., 2010; Makandar et al., 2012). From the current study, endogenous SA content (Total and conjugated SA) increased in Jiuyuehuang than in Nadou12 which suggests the accumulation of SA as a result of the fungal infection.

The result from the gene expression analysis indicated that more defense genes were expressed in Nandou12 than in Jiuyuehuang. The expression of NPR1 was also up-regulated in Nandou12 than in Jiuyuehuang indicating that the gene expression involved in SA signaling pathways was up-regulated in Nandou12 than in Jiuyuehuang. We suggest from the current result that in the event of fungal stress in soybean, SA mediated disease resistance plays an important role in Nandou12 resistance to $F$. solani.

In addition, results from the current study also showed that there was an increase in Peroxidase (POD), superoxide dismutase (SOD) and malondialdehyde (MDA) as a result of the fungal stress (Figure 7). SOD is one important enzyme in ROS metabolism and catalyzes the dismutation of oxygen $\left(\mathrm{O}_{2}\right)$ - and hydrogen peroxide $\left(\mathrm{H}_{2} \mathrm{O}_{2}\right)$ (Gill \& Tuteja, 2010). Increased and decrease in SOD activity have frequently been correlated with disease resistance and susceptibility (Yang et al., 2003). Vanacker et al. (1998) reported that an increase in SOD activity following pathogen attack might be required to catalyze the synthesis of $\mathrm{H}_{2} \mathrm{O}_{2}$ during the oxidative burst and to prevent the accumulation of superoxide. The current study recorded an increase in SOD activity in the fungal infected plants of Nandou12 more than the fungal infected plants of Jiuyuehuang. Similar result was recorded in the POD level with increased activity in the fungal infected plants of the resistant cultivar than in fungal infected plants of the susceptible cultivar. This suggests that antioxidant defense mechanism activated under stress remained operative throughout that challenging period, enabling plants to adopt to such conditions (Pérez-Clemente et al., 2012). MDA is one final decomposition product of lipid peroxidation and has been used as an index for the presence of lipid peroxidation (Esim et al., 2012). While more ROS was accumulated, more MDA was also accumulated in Nandou12 (Figures 3d and 7c) respectively. Which we conclude that the fungal stress had more damaging effect on Jiuyuehuang more than the Nandou12. MDA content increased in water stressed olive plants which has resemblance with our results (Sofo et al., 2004). The increased level of activated oxygen species could contribute to the symptoms development and pathogenesis in compatible plant-virus interactions. In the current study, the higher level in ROS is consistent with the increase in $\mathrm{H}_{2} \mathrm{O}_{2}$ activity (Xi et al., 2007).

\section{Conclusion}

In conclusion, $F$. solani infection revealed disease symptoms in Jiuyuehuang with no disease symptoms in Nandou12. The plant cells stained by DAB and Trypan blue produced a high amount of ROS and cell death in the area of infection respectively. Enzymatic and non-enzymatic antioxidative pathways which are involved in the production of signaling molecules were increased in Jiuyuehuang. More $P R$ genes were induced in Nandou12. The current findings suggest that these differences are associated with resistance. SA treatment of both cultivars rendered them more resistant to $F$. solani. The current results can provide novel insights for better recognition of the responsible mechanisms needed to regulate SDS resistance in soybean. The direct effect of SA should further be examined on the above-mentioned enzyme activities and their gene expression in conferring resistance to pathogens. Exogenous SA application was able to induce SAR against $F$. solani of which we propose that SA played this role through regulation of the plant antioxidative system or through the genes involve in the SA signaling pathways.

\section{References}

Bari, R., \& Jones, J. D. G. (2009). Role of hormones in plant defense responses. Plant Molecular Biology, 69(4), 473-488. https://doi.org/10.1007/s11103-008-9435-0

Benhamou, N., \& Bélanger, R. R. (1998). Benzothiadiazole-Mediated Induced Resistance to Fusarium oxysporum f. sp.radicis-lycopersici in Tomato. Plant Physiology, 118(4), 1203-1212. https://doi.org/ 10.1104/pp.118.4.1203

De, V. M., Van Oosten, V. R., Van Poecke, R. M., Van Pelt, J. A., Pozo, M. J., \& Mueller, M. J. (2005). Signal signature and transcriptome changes of Arabidopsis during pathogen and insect attack. Molecular Plant-Microbe Interactions, 18(9), 923-937. https://doi.org/10.1094/MPMI-18-0923

Dempsey, D. A., Shah, J., \& Klessig, D. F. (1997). Salicylic acid and disease resistance in plants. Critical Reviews in Plant Sciences, 18(4), 547-575. https://doi.org/10.1080/07352689991309397 
Dixon, R. A., And, M. J. H., \& Lamb, C. J. (1994). Early Events in the Activation of Plant Defense Responses. Annual Review of Phytopathology, 32(32), 479-501. https://doi.org/10.1146/annurev.py.32.090194.002403

Du, J., Zhao, B., Sun, X., Zhang, D., Zhang, S., \& Yang, W. (1893). Identification and characterization of multiple intermediate alleles of the key genes regulating brassinosteroid biosynthesis pathways. Frontiers in Plant Science, 7.

Du, J. B., Yuan, S., Chen, Y. E., Sun, X., Zhang, Z. W., \& Xu, F. (2011). Comparative expression analysis of dehydrins between two barley varieties, wild barley and Tibetan hulless barley associated with different stress resistance. Acta Physiologiae Plantarum, 33(2), 567-574. https://doi.org/10.1007/s11738-010-0580-0

Durrant, W. E., \& Dong, X. (2004). Systemic Acquired Resistance. Annual Review of Phytopathology, 42(1), 185-209. https://doi.org/10.1146/annurev.phyto.42.040803.140421

Edgar, C. I., Mcgrath, K. C., Dombrecht, B., Manners, J. M., Maclean, D. C., \& Schenk, P. M. (2006). Salicylic acid mediates resistance to the vascular wilt pathogen Fusarium oxysporum in the model host Arabidopsis thaliana. Australasian Plant Pathology, 35(6), 581-591. https://doi.org/10.1071/AP06060

Egley, G. H., Paul, R. N., Vaughn, K. C., \& Duke, S. O. (1983). Role of peroxidase in the development of water-impermeable seed coats in Sida spinosa L. Planta, 157(3), 224-232. https://doi.org/10.1007/BF00 405186

Esim, N., Atici, O., \& Mutlu, S. (2012). Effects of exogenous nitric oxide in wheat seedlings under chilling stress. Toxicology \& Industrial Health, 30(3), 268-274. https://doi.org/10.1177/0748233712457444

Giannopolitis, C. N., \& Ries, S. K. (2010). Superoxide dismutases. Ciba Foundation Symposium, 79(10), 61-97.

Gill, S. S., \& Tuteja, N. (2010). Reactive oxygen species and antioxidant machinery in abiotic stress tolerance in crop plants. Plant Physiology \& Biochemistry, 48(12), 909-930. https://doi.org/10.1016/j.plaphy.2010. 08.016

Glazebrook, J. (2015). Contrasting Mechanisms of Defense Against Biotrophic and Necrotrophic Pathogens. Annual Review of Phytopathology, 43(1), 205-227. https://doi.org/10.1146/annurev.phyto.43.040204. 135923

Glazebrook, J., Chen, W., Estes, B., Chang, H. S., Nawrath, C., \& Métraux, J. P. (2003). Topology of the network integrating salicylate and jasmonate signal transduction derived from global expression phenotyping. Plant Journal for Cell \& Molecular Biology, 34(2), 217-228. https://doi.org/10.1046/ j.1365-313X.2003.01717.x

Görlach, J., Volrath, S., Knaufbeiter, G., Hengy, G., Beckhove, U., \& Kogel, K. H. (1996). Benzothiadiazole, a novel class of inducers of systemic acquired resistance, activates gene expression and disease resistance in wheat. Plant Cell, 8(4), 629-643. https://doi.org/10.2307/3870340

Haas, J. H., \& Buzzell, R. I. (1976). New races 5 and 6 of Phytophthora megasperma var. sojae and differential reactions of soybean cultivars for races 1 to 6. Phytopathology, 66(11), 1361-1362. https://doi.org/10.1094/ Phyto-66-1361

Hu, G., Dehart, A. K., Li, Y., Ustach, C., Handley, V., \& Navarre, R. (2005). EDS1 in tomato is required for resistance mediated by TIR-class R genes and the receptor-like R gene Ve. Plant Journal, 42(3), $376-391$. https://doi.org /10.1111/j.1365-313X.2005.02380.x

Ishikawa, R., Shirouzu, K., Nakashita, H., Lee, H. Y., Motoyama, T., \& Yamaguchi, I. (2015). Foliar spray of validamycin a or validoxylamine a controls tomato fusarium wilt. Phytopathology, 95(10), 1209-1216. https://doi.org/10.1094/PHYTO-95-1209

Katz, V. A., Thulke, O. U., \& Conrath, U. (1998). A benzothiadiazole primes parsley cells for augmented elicitation of defense responses. Plant Physiology, 117(4), 1333-1339. https://doi.org/10.1104/pp.117. 4.1333

Koornneef, A., \& Pieterse, C. M. J. (2008). Cross Talk in Defense Signaling. Plant Physiology, $146(3), 839$. https://doi.org/10.1104/pp.107.112029

Lam, E. (2004). Controlled cell death, plant survival and development. Nat Rev Mol Cell Biol, 5(4), $305-315$. https://doi.org/10.1038/nrm1358

Lamb, C., \& Dixon, R. A. (1997). The Oxidative Burst in Plant Disease Resistance. Annual Review of Plant Physiology and Plant Molecular Biology, 48(1), 251-275. https://doi.org/10.1146/annurev.arplant.48.1.251 
Lee, D. H., \& Lee, C. B. (2000). Chilling stress-induced changes of antioxidant enzymes in the leaves of cucumber: In gel enzyme activity assays. Plant Science An International Journal of Experimental Plant Biology, 159(1), 75-85. https://doi.org/10.1016/S0168-9452(00)00326-5

Levine, A. (2000). The hypersensitive response facilitates plant infection by the necrotrophic pathogen Botrytis cinerea. Current Biology, 10(13), 751-757. https://doi.org/10.1016/S0960-9822(00)00560-1

Liu, J., Tian, S., Meng, X., \& Xu, Y. (2007). Effects of chitosan on control of postharvest diseases and physiological responses of tomato fruit. Postharvest Biology \& Technology, 44(3), 300-306. https://doi.org/ 10.1016/j.postharvbio.2006.12.019

Loake, G., \& Grant, M. (2007). Salicylic acid in plant defence-The players and protagonists. Current Opinion in Plant Biology, 10(5), 466-472. https://doi.org/10.1016/j.pbi.2007.08.008

Luo, Y., Shang, J., Zhao, P., Xi, D., Yuan, S., \& Lin, H. (2011). Application of Jasmonic Acid Followed by Salicylic Acid Inhibits Cucumber mosaic virus Replication. Plant Pathology Journal, 27(1). https://doi.org/ 10.5423/PPJ.2011.27.1.053

Makandar, R., Essig, J. S., Schapaugh, M. A., Trick, H. N., \& Shah, J. (2006). Genetically engineered resistance to Fusarium head blight in wheat by expression of Arabidopsis NPR1. Molecular Plant-Microbe Interactions, 19(2), 123-129. https://doi.org/10.1094/MPMI-19-0123

Makandar, R., Nalam, V., Chaturvedi, R., Jeannotte, R., Sparks, A. A., \& Shah, J. (2010). Involvement of salicylate and jasmonate signaling pathways in Arabidopsis interaction with Fusarium graminearum. Molecular Plant-Microbe Interactions, 23(7), 861-870. https://doi.org/10.1094/MPMI-23-7-0861

Makandar, R., Nalam, V. J., Lee, H., Trick, H. N., Dong, Y., \& Shah, J. (2012). Salicylic acid regulates basal resistance to Fusarium head blight in wheat. Molecular Plant-Microbe Interactions, 25(3), 431-439. http://doi.org/10.1094/MPMI-09-11-0232

Oostendorp, M., Kunz, W., Dietrich, B., \& Staub, T. (2001). Induced Disease Resistance in Plants by Chemicals. European Journal of Plant Pathology, 107(1), 19-28. https://doi.org/10.1023/A:1008760518772

Pérez-Clemente, R. M., Vives, V., Zandalinas, S. I., López-Climent, M. F., Muñoz, V., \& Gómez-Cadenas, A. (2013). Biotechnological approaches to study plant responses to stress. BioMed Research International. https://doi.org/10.1155/2013/654120

Qian, G., Han, Z., Zhao, T., Deng, G., Pan, Z., \& Yu, M. (2007). Genotypic variability in sequence and expression of HVA1 gene in Tibetan hulless barley, Hordeum vulgare ssp. vulgare, associated with resistance to water deficit. Australian Journal of Agricultural Research, 58(5), 425-431. https://doi.org/ 10.1071/AR06300

Robert-Seilaniantz, A., Navarro, L., Bari, R., \& Jones, J. D. G. (2007). Pathological hormone imbalances. Current Opinion in Plant Biology, 10(4), 372-379. https://doi.org/10.1016/j.pbi.2007.06.003

Roy, K. W., Rupe, J. C., Hershman, D. E., \& Abney, T. S. (1997). Sudden death syndrome of soybean. Plant Disease, 81(10), 1100-1111. https://doi.org/10.1094/PDIS.1997.81.10.1100

Scandiani, M. M., Ruberti, D. S., Giorda, L. M., Pioli, R. N., Luque, A. G., \& Bottai, H. (2011). Comparison of inoculation methods for characterizing relative aggressiveness of two soybean sudden-death syndrome pathogens, Fusarium virguliforme and $F$. tucumaniae Comparação de métodos de inoculação para a caracterização de agressividade relativa. Tropical Plant Pathology, 36(3), 133-140. https://doi.org/10.15 90/S1982-56762011000300001

Sharma, P., Jha, A. B., Dubey, R. S., \& Pessarakli, M. (2012). Reactive Oxygen Species, Oxidative Damage, and Antioxidative Defense Mechanism in Plants under Stressful Conditions. Journal of Botany. https://doi.org/ $10.1155 / 2012 / 217037$

Shirasu, K., Lahaye, T., Tan, M. W., Zhou, F., Azevedo, C., \& Schulzelefert, P. (1999). A novel class of eukaryotic zinc-binding proteins is required for disease resistance signaling in barley and development in $\mathrm{C}$. elegans. Cell, 99(4), 355-366. https://doi.org/10.1016/S0092-8674(00)81522-6

Singh, V. K., \& Upadhyay, R. S. (2014). Fusaric acid induced cell death and changes in oxidative metabolism of Solanum lycopersicum L. Botanical Studies, 55(1), 1-11. https://doi.org/10.1186/s40529-014-0066-2

Sofo, A., Dichio, B., Xiloyannis, C., \& Masia, A. (2004). Effects of different irradiance levels on some antioxidant enzymes and on malondialdehyde content during rewatering in olive tree. Plant Science, 166(2), 293-302. https://doi.org/10.1016/j.plantsci.2003.09.018 
Spletzer, M. E., \& Enyedi, A. J. (1999). Salicylic Acid Induces Resistance to Alternaria solani in Hydroponically Grown Tomato. Phytopathology, 89(9), 722. https://doi.org/10.1094/PHYTO.1999.89. 9.722

Sumayo, M. S., Kwon, D. K., \& Ghim, S. Y. (2014). Linoleic acid-induced expression of defense genes and enzymes in tobacco. Journal of Plant Physiology, 171(18), 1757-1762. https://doi.org/10.1016/j.jplph. 2014.08.015

Sun, X., Yuan, S., \& Lin, H. H. (2006). Salicylic acid decreases the levels of dehydrin-like proteins in Tibetan hulless barley leaves under water stress. Zeitschrift Fur Naturforschung C A Journal of Biosciences, 61(4), 245-250. https://doi.org/10.1515/znc-2006-3-415

Thaler, Jennifer, S., Humphrey, Parris, T., Whiteman, \& Noah, K. (2012). Evolution of jasmonate and salicylate signal crosstalk. Trends in Plant Science, 17(5), 260-270. https://doi.org/10.1016/j.tplants.2012.02.010

Thordal-Christensen, H., Zhang, Z., Wei, Y., \& Collinge, D. B. (1997). Subcellular localization of $\mathrm{H}_{2} \mathrm{O}_{2}$ in plants. $\mathrm{H}_{2} \mathrm{O}_{2}$ accumulation in papillae and hypersensitive response during the barley-Powdery mildew interaction. Plant Journal, 11(6), 1187-1194. https://doi.org/10.1046/j.1365-313X.1997.11061187.x

Uknes, S., Mauch-Mani, B., Moyer, M., Potter, S., Williams, S., \& Dincher, S. (1992). Acquired resistance in Arabidopsis. Plant Cell, 4(6), 645-656. https://doi.org/10.1105/tpc.4.6.645

Vanacker, H., Harbinson, J., Ruisch, J., Carver, T. L. W., \& Foyer, C. H. (1998). Antioxidant defence of the apoplast. Protoplasma, 205(1), 129-140. https://doi.org/10.1007/BF01279303

Wang, G. F., Seabolt, S., Hamdoun, S., Ng, G., Park, J., \& Lu, H. (2011). Multiple roles of WIN3 in regulating disease resistance, cell death, and flowering time in Arabidopsis. Plant Physiology, 156(3), 1508-1519. https://doi.org/10.1104/pp.111.176776

Ward, E. R., Uknes, S. J., Williams, S. C., Dincher, S. S., Wiederhold, D. L., \& Alexander, D. C. (1991). Coordinate gene activity in response to agents that induce systemic acquired resistance. Plant Cell, 3(10), 1085-1094. https://doi.org/10.1105/tpc.3.10.1085

Wege, C., \& Siegmund, D. (2007). Synergism of a DNA and an RNA virus: Enhanced tissue infiltration of the begomovirus Abutilon mosaic virus (AbMV) mediated by Cucumber mosaic virus (CMV). Virology, 357(1), 10-28. https://doi.org/10.1016/j.virol.2006.07.043

Wrather, A., Shannon, G., Balardin, R., Carregal, L., Escobar, R., \& Gupta, G. K. (2010). Effect of diseases on soybean yield in the top eight producing countries in 2006. Plant Health Progress. https://doi.org/ 10.1094/PHP-20100125-01-RS.

Xi, D., Feng, H., Lan, L., Du, J., Wang, J., \& Zhang, Z. (2007). Characterization of Synergy between Cucumber mosaic virus and Tobacco necrosis virus in Nicotiana benthamiana. Journal of Phytopathology, 155(9), 570-573. http://doi.org/10.1111/j.1439-0434.2007.01279.x

Yan, S., \& Dong, X. (2014). Perception of the plant immune signal salicylic acid. Current Opinion in Plant Biology, 20, 64-68. https://doi.org/10.1016/j.pbi.2014.04.006

Yang, Y., Liang, Y., Lou, Y., \& Sun, W. (2003). Influences of silicon on peroxidase, superoxide dismutase activity and lignin content in leaves of wheat (Ttritium aestivum $\mathrm{L}$.) and its relation to resistance to powdery mildew. Scientia Agricultura Sinica, 3(6), 813-817.

Zhang, J., Cui, S., Li, J., Wei, J., \& Kirkham, M. B. (1995). Protoplasmic factors, antioxidant responses, and chilling resistance in maize. Plant Physiology \& Biochemistry, 33(5), 567-575.

Zheng, Q. F., \& Dong, X. (2013). Systemic Acquired Resistance: Turning Local Infection into Global Defense. Annual Review of Plant Biology, 64(1), 839-863. https://doi.org/10.1146/annurev-arplant-042811-105606

\section{Copyrights}

Copyright for this article is retained by the author(s), with first publication rights granted to the journal.

This is an open-access article distributed under the terms and conditions of the Creative Commons Attribution license (http://creativecommons.org/licenses/by/4.0/). 